\title{
USTAWY W ZAKRESIE ZAPEWNIANIA BEZPIECZEŃSTWA WEWNĘTRZNEGO (INTERNAL SECURITY ACTS) W INDIACH, PORTUGALII I FRANCJI
}

Zapewnianie bezpieczeństwa wewnętrznego we współczesnych państwach jest obecnie jednym z kluczowych wyzwań, z którymi muszą się zmierzyć ich władze. W tym celu poszczególne rządy przyjmują różne rozwiązania, zarówno na gruncie prawnym, jak i politycznym oraz o charakterze operacyjnym. O ich kształcie decyduje specyfika danego państwa, jego systemu prawnego, politycznego, członkostwo (bądź jego brak) w danych organizacjach międzynarodowych, takich jak np. Unia Europejska (UE) etc. W szczególności godne zainteresowania są rozwiązania natury prawnej, czyli ustawy o bezpieczeństwie wewnętrznym (Internal Security Acts), przyjmowane przez niektóre z państw, takie jak (niegdyś) Indie, a współcześnie chociażby Portugalia oraz Francja.

Tematem podejmowanym $w$ artykule są rozwiązania prawne w zakresie zapewniania bezpieczeństwa wewnętrznego przyjęte w Indiach, Portugalii oraz we Francji. Wskazano państwa te $\mathrm{z}$ tego względu, że przyjmowały one, w różnym okresie i z różnych powodów, ustawy, które wprost mówiły o bezpieczeństwie wewnętrznym i często takie też nosiły nazwy. Dokonano analizy ustaw o bezpieczeństwie wewnętrznym, które przyjmowano w wymienionych państwach, przy czym zwrócono uwagę na czynniki, które wpłynęły na ostateczny kształt uregulowań prawnych. Założono, że punktem wyjściowym do budowania efektywnego systemu bezpieczeństwa wewnętrznego w danym państwie jest zdefiniowanie bezpieczeństwa wewnętrznego, a definicja taka może znaleźć się właśnie w ustawie o bezpieczeństwie wewnętrznym. Pytania badawcze dotyczą tego w jaki sposób pojmuje się bezpieczeństwo wewnętrzne na gruncie ustawodawstwa w tym zakresie w Indiach, Portugalii oraz we Francji, przy czym przyjęto perspektywę historyczną (badając nieobowiązujący już akt w Indiach) i współczesną (ustawy w Portugalii i we Francji).

\section{USTAWA O UTRZYMANIU BEZPIECZEŃSTWA WEWNĘTRZNEGO W INDIACH Z 1971 R.}

Przyjęta w 1971 r. w Indiach, za czasów premier Indiry Ghandi, ustawa o utrzymaniu bezpieczeństwa wewnętrznego (ang. Maintenance of Internal Security Act - MISA) była niewątpliwie kontrowersyjna ze względu na zarzucane jej godzenie w podstawowe prawa i wolności człowieka przez ograniczanie wolności osobistej, co pociągnęło 
za sobą uchylenie ustawy kilka lat później. MISA zastappiła przyjęte przez prezydenta Indii kilka miesięcy wcześniej rozporządzenie o utrzymaniu bezpieczeństwa wewnętrznego. Co jednak ważne, już w samej nazwie tej ustawy wprowadza się pojęcie „bezpieczeństwo wewnętrzne” (ang. internal security).

Regulacja przewidziana we wspomnianych wyżej aktach prawnych, budząca kontrowersje, czyli możliwość prewencyjnego aresztowania (ang. preventive detention) tj. bez rozprawy sądowej tych, którzy byli uznani za narażających na szwank bezpieczeństwo Indii była zresztą obecna w porządku prawnym Indii wcześniej, jeszcze przed przyjęciem konstytucji w 1950 r. (Abraham, 1993: 59). Uwagę zwraca fakt, że zapis ten może być zastosowany w sprawach związanych z obrona, stosunkami zagranicznymi, bezpieczeństwem Indii, utrzymaniem porządku publicznego bądź zakłóceniem dostaw podstawowych dóbr i usług, niezbędnych do egzystencji mieszkańców. Czynniki, które niewątpliwie wpłynęły na rozwijanie uregulowań prawnych w takim kierunku wiązały się z burzliwą historią Indii, kwestią Pakistanu i wynikającymi stąd perturbacjami politycznymi, społecznymi, gospodarczymi etc. (ibidem: 60). Należy zaznaczyć, że w czasach współczesnych, w znowelizowanej konstytucji Indii w art. 22 zdecydowano się utrzymać zapis o prewencyjnym aresztowaniu pod pewnymi warunkami (The Constitution of India, 2015).

Kształt zapisów w ustawie o utrzymaniu bezpieczeństwa wewnętrznego z $1971 \mathrm{r}$. jest interesujący z poznawczego punktu widzenia - w kontekście badania sposobów rozumienia bezpieczeństwa wewnętrznego we współczesnych państwach. W pełnej nazwie ustawy zapisano, że jest ona przyjmowana w celu umożliwienia ograniczenia wolności ( $\mathrm{tj}$. uwięzienia) w związku z dążeniem władz do zapewniania bezpieczeństwa wewnętrznego państwu, zatem już sama nazwa budziła kontrowersje. Niemniej jednak, biorąc pod uwagę problem poruszany w artykule, warto zwrócić uwagę na siatkę pojęciową zastosowana przez ustawodawcę. Przede wszystkim przywoływane są takie terminy, jak: „obrona Indii”, „bezpieczeństwo Indii”, „bezpieczeństwo państwa”, „utrzymanie porządku publicznego”, ,utrzymanie dostaw [dóbr] i usług żywotnych dla społeczeństwa" (Maintenance of Internal Security Act, 1971: art. 3). W tym miejscu trzeba podkreślić, że w ustawie pojęć tych nie wyjaśniono, natomiast w dalszej części aktu ustawodawca skoncentrował się na kwestiach związanych z ograniczaniem wolności osobistej, w tym cudzoziemców przebywających w Indiach. Położenie akcentu na regulacjach tego rodzaju implikuje wąskie rozumienie bezpieczeństwa wewnętrznego, czyli utożsamianie go z pojęciami porządku publicznego i bezpieczeństwa publicznego. Potwierdzają to stwierdzenie zapisy art. 17 MISA, w którym rozstrzyga sie kwestię aresztowania cudzoziemców wkraczających bądź podejmujących próbę wkroczenia na terytorium Indii i będących w posiadaniu broni, amunicji lub materiałów wybuchowych, czyli - jak można wnioskować - ustawodawca miał tu na myśli potencjalnych wywrotowców, terrorystów (ibidem).

Ostatecznie ustawa o utrzymaniu bezpieczeństwa wewnętrznego, po kilku nowelizacjach dokonanych w kolejnych latach, przestała obowiązywać w 1978 r., gdy Indira Ghandi przestała być premierem. Nie oznaczało to jednak, że problematyka bezpieczeństwa wewnętrznego straciła na znaczeniu - w dalszym ciągu obowiązywały inne akty prawne (kolejno nowelizowane) i dokumenty z tego zakresu, utrzymane w duchu ustawy, zarówno dotyczące specjalnych uprawnień wojska w zakresie zadań bezpie- 
czeństwa wewnętrznego, jak i innych służb. Uwagę zwraca ustawa o specjalnych uprawnieniach sił zbrojnych z $1958 \mathrm{r}$. z późniejszymi zmianami, w której ustawodawca przewidział dla władz możliwość ,[...] w tak niespokojnych lub niebezpiecznych okolicznościach, że w potrzebie wykorzystanie sił zbrojnych w celu pomocy władzom cywilnym [...]" jest dopuszczalne (The Armed Forces (Special Powers) Act, 1958, art. 3). Zapisy tej ustawy budziły krytykę i pojawiały się głosy postulujące jej uchylenie (Ramachandran, 2015). Innym ważnym aktem była ustawa o zapewnianiu żywotnych usług, kluczowych z punktu funkcjonowania społeczeństwa, czyli - jak sprecyzował to ustawodawca - głównie usług komunikacyjnych (The Essential Services Maintenance Act, 1968: art. 1). Poprzedniczką ustawy o utrzymaniu bezpieczeństwa wewnętrznego była natomiast ustawa o ochronie handlu zagranicznego i zapobieganiu przemytu z 1974 r. (ang. the Conservation of Foreign Exchange and Prevention of Smuggling Activities Act), która dawała możliwość prewencyjnego uwięzienia tych, którzy przez swoją działalność narażali na szwank ,[...] gospodarkę narodową [...] i bezpieczeństwo państwa [...]" (ibidem). Z kolei wśród późniejszych aktów prawnych uwage zwraca ustawa o bezpieczeństwie narodowym z 1980 r. (ang. the National Security Act), która - mimo wskazującej na to nazwy - nie dotyczy spraw wiążących się stricte z problematyką bezpieczeństwa narodowego, tj. bezpieczeństwa zarówno w wewnętrznym, jak i zewnętrznym wymiarze, lecz zwłaszcza tych, które początkowo regulowała MISA, tj. m.in. kwestii prewencyjnego uwięzienia. Wymieniony katalog uzupełniały ustawa o działalności terrorystycznej i zakłócającej porządek z 1987 r. (ang. Terrorist and Disruptive Activities (Prevention) Act) oraz ustawa o zapobieganiu terroryzmowi z 2002 r. (ang. the Prevention of Terrorism Act).

Zwraca uwagę to, że we wszystkich wymienionych wyżej aktach prawnych przyjmowanych na przestrzeni kolejnych lat nie zdefiniowano wprost pojęcia bezpieczeństwa wewnętrznego, chociaż właśnie problematyki z tego zakresu dotyczyły zawarte w nich zapisy. Można jednak stwierdzić, że zakres pojęciowy bezpieczeństwa wewnętrznego $\mathrm{w}$ przypadku Indii jest traktowany wąsko, sprowadza się do - jak już wyżej wspomniano - kwestii związanych z utrzymaniem bezpieczeństwa publicznego i porządku publicznego, co uwarunkowane jest historią i sytuacją polityczną tego państwa.

\section{USTAWA O BEZPIECZEŃSTWIE WEWNĘTRZNYM W PORTUGALII Z 2008 R.}

Innym państwem, członkiem zarówno Unii Europejskiej, jak i Sojuszu Północnoatlantyckiego, które także dokonało ustawowych uregulowań w obszarze bezpieczeństwa wewnętrznego jest Portugalia. W jej przypadku należy zwrócić uwagę na moment przełomowy, czyli lata 70. XX w., kiedy upada dotychczasowy reżim (w 1974 r.), a do ustawy zasadniczej wprowadza się zapisy odnoszące się do problematyki zapewniania bezpieczeństwa wewnętrznego. Mianowicie, w art. 272 wskazuje się służby odpowiedzialne za utrzymywanie bezpieczeństwa wewnętrznego w państwie, tj. siły policyjne, którymi są policja oraz Narodowa Gwardia Republikańska (port. Constitution of the Portuguese Republic, 1976). Kluczowe, z punktu widzenia problematyki tego arty- 
kułu, było przyjęcie w 1987 r. ustawy o bezpieczeństwie wewnętrznym Portugalii, w obecnej wersji obowiązującej od 2008 r.

Przygotowując się do przyjęcia ustawy o bezpieczeństwie wewnętrznym, rząd byłego premiera Portugalii José Sócratesa przeprowadził szereg bardzo ważnych i szeroko zakrojonych reform w zakresie bezpieczeństwa wewnętrznego w 2007 r., mających na celu utworzenie ogólnokrajowego, nowoczesnego zintegrowanego systemu bezpieczeństwa wewnętrznego (port. Sistema Integrado de Segurança Interna - SISI). António Costa, minister administracji wewnętrznej w rządzie Sócratesa, a następnie burmistrz Lizbony, w sześciu punktach podsumował konieczność przeprowadzenia reform: 1) nastappiła dezaktualizacja koncepcji bezpieczeństwa wewnętrznego Portugalii, określonej w ustawie z 1987 r., która w czasach współczesnych, gdy zmienił się charakter zagrożeń dla bezpieczeństwa i mamy do czynienia ze zjawiskami takimi, jak terroryzm, nie spełnia już swojej roli; minister zapowiedział wtedy przyjęcie nowej ustawy; 2) niekwestionowany brak koordynacji, wiążący się z tym, że Portugalia posiada różne siły i służby przeznaczone do różnorodnych zadań w sferze bezpieczeństwa wewnętrznego; by podnieść skuteczność funkcjonowania służb, należy wprowadzić system koordynacji ich działań, tworząc w tym celu zintegrowany system bezpieczeństwa wewnętrznego; jest to kluczowy punkt reform; 3) konieczność zacieśniania związków i współpracy między Narodową Gwardią Republikańską i policja, jednak przy zachowaniu ich odrębnej tożsamości, a także konieczność wyeliminowania sytuacji, w których zadania tych instytucji wzajemnie się na siebie nakładają; 4) konieczność racjonalizacji środków (materialnych i kadrowych) oraz procedur w strukturach policji i gwardii; 5) wprowadzenie rozwiązań i środków mających na celu zwiększenie skuteczności służby policjantów i gwardzistów; 6) zapewnienie wzrostu inwestycji w siły bezpieczeństwa, lecz bez zwiększania deficytu budżetowego (Costa, 2007; Marczuk, 2012 : 197).

Ustawa o bezpieczeństwie wewnętrznym Portugalii z 2008 r. przede wszystkim określa zakres pojmowania bezpieczeństwa wewnętrznego w tym państwie. Reformy rządu w sprawach wewnętrznych kończyło przyjęcie ustawy o organizacji dochodzeń kryminalnych z 2008 r. (port. Lei de Organização da Investigação Criminal).

Kluczowym zapisem ustawy o bezpieczeństwie wewnętrznym, uwzględnionym przez ustawodawcę - w odróżnieniu od zapisów ustawy przyjętej w Indiach - jest definicja bezpieczeństwa wewnętrznego. Bezpieczeństwo wewnętrzne rozumie się zatem jako ,[...] aktywność podejmowaną przez Państwo w celu zapewniania porządku, bezpieczeństwa i spokoju publicznego, ochrony osób i mienia, powstrzymywania i tłumienia przestępczości, jak również przyczyniania się do wspierania normalnego funkcjonowania instytucji demokratycznych, stałego przestrzegania prawa, wolności i praw podstawowych obywateli oraz poszanowania demokratycznej legalności. [...] Środki przewidziane w niniejszej ustawie są przeznaczone w szczególności w celu ochrony życia i bezpieczeństwa ludzi, spokoju publicznego i porządku demokratycznego, [środki te są podejmowane] zwłaszcza przeciwko terroryzmowi, brutalnej przestępczości lub wysoko zorganizowanej, sabotażowi, szpiegostwu, w celu zapobiegania i reagowania na znaczace awarie lub katastrofy, ochrony środowiska oraz ochrony zdrowia publicznego" (Lei de Segurança Interna, 2008: art. 1.1, 1.3). Takie zdefiniowanie pojęcia bezpieczeństwa wewnętrznego oznacza, że władze Portugalii zdecydo- 
wały się przyjąc szerokie podejście do bezpieczeństwa wewnętrznego, m.in. kładąc nacisk na zapobieganie i reagowanie na zagrożenia naturalne i powodowane działalnością człowieka, godzące w życie i zdrowie ludzi, lecz także bezpieczeństwo państwa. Co więcej, w ustawie wyjaśniono także pojęcie polityki bezpieczeństwa wewnętrznego, ujmując ją jako zbiór zasad, celów, priorytetów i wytycznych oraz środków, które należy przedsięwziąć w celu osiągnięcia bezpieczeństwa wewnętrznego (ibidem: art. 3). Ponadto na obywateli (społeczeństwo) nałożono obowiązek współpracy w osiaganiu bezpieczeństwa wewnętrznego, specjalną rolę wyznaczając zwłaszcza tym, którzy pracują oraz wojskowym (ibidem: art. 5.1, 5.2).

Omawiając zakres pojęciowy ustawy o bezpieczeństwie wewnętrznym w Portugalii, trzeba wskazać, że ustawodawca uwzględnił aktywność tego państwa na forum międzynarodowym, czyli członkostwo Portugalii w Unii Europejskiej i związaną z tym współpracę w sprawach wewnętrznych, jak również z innymi organizacjami międzynarodowymi. Siły bezpieczeństwa Portugalii mogą wypełniać swoje zadania również poza granicami państwa - zapis taki uwzględnia współczesny trend ku internacjonalizacji bezpieczeństwa wewnętrznego, czyli proces przenikania granic przez zagrożenia o charakterze wewnętrznym (ibidem: art. 4; Marczuk, 2012: 199).

Przywołana zapowiedź ministra Antónia Costy, dotycząca budowy zintegrowanego systemu bezpieczeństwa wewnętrznego, znalazła odzwierciedlanie w środkach prawnych - w ustawie o bezpieczeństwie wewnętrznym szczegółowo określono kompetencje w zakresie polityki bezpieczeństwa wewnętrznego głównych organów w tym zakresie, czyli Zgromadzenia Republiki, rządu oraz premiera, który ponosi polityczną odpowiedzialność za prowadzenie polityki bezpieczeństwa wewnętrznego (Lei de Segurança Interna, 2008; art. 7-9). Uwagę poświęcono również organizacji systemu bezpieczeństwa wewnętrznego, którego organami na szczeblu centralnym są: organ o charakterze opiniodawczo-doradczym i konsultacyjnym, czyli Wysoka Rada Bezpieczeństwa Wewnętrznego, Sekretarz Generalny Systemu Bezpieczeństwa Wewnętrznego podlegający premierowi, koordynujący, nadzorujący i zarządzający funkcjonowaniem systemu, a także podlegające premierowi Biuro Koordynacji Bezpieczeństwa, organ doradczy o charakterze technicznym. Tym samym ustawa nadała konkretny kształt rozwiązaniom instytucjonalnym w zakresie bezpieczeństwa wewnętrznego Portugalii.

\section{USTAWY O BEZPIECZEŃSTWIE WEWNĘTRZNYM WE FRANCJI W LATACH 1995-2011}

W przypadku rozwiązań prawnych zastosowanych we Francji szczególną uwagę zwraca to, że władze tego państwa zdecydowały się na odpowiedź na gruncie prawnym na zagrożenia $z$ obszaru bezpieczeństwa wewnętrznego, koncentrując się zwłaszcza na zagrożeniach związanych $\mathrm{z}$ terroryzmem. Francja dotknięta jest tym zagrożeniem już od dawna, przy czym początkowo był to tzw. terroryzm o charakterze wewnętrznym (m.in. działalność Action Direct), terroryzm związany z dążeniami do oderwania od Francji części Baskonii i Bretanii oraz Korsyki, współcześnie - terroryzm o zabarwieniu międzynarodowym (Shapiro, Suzan, 2003: 69). W tym kontekście godne uwagi są 
ustawy o bezpieczeństwie wewnętrznym, przyjmowane we Francji, często uzupełniane przez inne akty prawne $\mathrm{z}$ zakresu bezpieczeństwa wewnętrznego ${ }^{1}$.

W połowie lat 90 . XX w. przyjęto kluczowy akt prawny, który dał podwaliny kolejnym regulacjom z obszaru bezpieczeństwa wewnętrznego - ustawę o kierunkach i programowaniu w zakresie bezpieczeństwa z 21 stycznia 1995 r., zwaną ustawą Pasqua (loi Pasqua), za prezydentury Françoisa Mitterranda i premierostwa Edouarda Balladura; sam Charles Pasqua był szefem resortu spraw wewnętrznych w latach 1986-1988, a następnie 1993-1995. O doniosłości tego aktu prawnego przesądza zawarcie w nim definicji bezpieczeństwa (w domyśle wewnętrznego), które sprecyzowano w sposób następujący: „Bezpieczeństwo jest fundamentalnym prawem i jednym z warunków wykonywania wolności indywidualnych i zbiorowych. Państwo ma obowiązek zapewnić bezpieczeństwo, czuwając na całym terytorium Republiki, obronę instytucji i interesów narodowych, w poszanowaniu prawa, utrzymując pokój (fr. la paix) i porządek publiczny (fr. l'ordre public), ochronę osób i dóbr" (Loi d'orientation et de programmation relative à la sécurité, 1995: art. 1). Podkreśla się tu wąski wymiar bezpieczeństwa wewnętrznego (mowa o pokoju i porządku publicznym), użyty termin ,pokój”, odnosi się zatem do zakresu pojęciowego bezpieczeństwa publicznego i porządku publicznego. Takie rozumienie bezpieczeństwa (wewnętrznego) potwierdziły kolejne akty prawne, chociażby ustawa o bezpieczeństwie powszednim (fr. Loi relative à la sécurité quotidienne - LSQ) z listopada 2001 r., koncentrująca się na zaostrzeniu sankcji w tych obszarach życia publicznego, które narażone są na zagrożenia dla bezpieczeństwa publicznego np. obrót bronią i amunicja, prawo ruchu drogowego, transportu lotniczego i morskiego.

Ustawa Pasqua zdeterminowała kierunek myślenia o sprawach bezpieczeństwa wewnętrznego na kolejne lata. Zdecydowany przełom stanowi dojście do władzy Nicolas Sarkozy'ego, który przywiązywał bardzo dużą wagę do zapewniania bezpieczeństwa wewnętrznego we Francji. W szczególności kluczowe stają się dwie kolejne ustawy o kierunkach i programowaniu w zakresie bezpieczeństwa wewnętrznego z lat 2002 i 2011, czyli tzw. LOPPSI I i II (skrót od nazw ustaw w języku francuskim, tj. Loi d'orientation et de programmation pour la sécurité intérieure).

LOPPSI I (2002 r.) określała kierunki polityki Francji w dziedzinie bezpieczeństwa wewnętrznego na lata 2003-2007. Sama nazwa tego aktu prawnego wskazuje, że dotyczy on bezpieczeństwa wewnętrznego, podczas gdy w przypadku ustawy Pasqua brak takiego uwypuklenia. W pierwszym aneksie do tej ustawy w sposób szczegółowy nakreślono wytyczne polityki w sprawach bezpieczeństwa wewnętrznego Francji, podtrzymując definicję bezpieczeństwa z ustawy Pasqua z 1995 r. (Loi d'orientation et de programmation pour la sécurité intérieure, 2002). Przyjęcie LOPPSI I powodowane było znaczącym wzrostem przestępczości (liczba popełnianych przestępstw wzrosła sześć razy w przedziale od 1950 do 2000 r.), głównie w latach 1991-2002, przy czym niewielki spadek czynów karalnych odnotowano jedynie w czasie przyjęcia ustawy Pasqua (1995 r.). W LOPPSI I podkreślono zwłaszcza potrzebę walki z przestępczością

1 Ze względu na obfitość regulacji prawnych z obszaru bezpieczeństwa wewnętrznego przyjętych we Francji w artykule skoncentrowano się tylko na kilku kluczowych. Szerzej na ten temat autorka pisała w innym miejscu (zob. Marczuk, 2012: 124-134). 
oraz potrzebę zapewnienia porządku publicznego i bezpieczeństwa publicznego (fr. l'ordre public et la sécurité publique) w państwie (ibidem: art. 5).

Kontynuacją działań prawnych w zakresie wzmacniania bezpieczeństwa wewnętrznego we Francji było przyjęcie w 2003 r. ustawy o bezpieczeństwie wewnętrznym (fr. Loi pour la sécurité intérieure - LSI), zwaną również ustawą Sarkozy'ego II, stanowiącą odpowiedź legislacyjną na wzrost zagrożeń o charakterze wewnętrznym. Wprowadzono penalizację nowych rodzajów przestępstw (prostytucja, żebractwo, nielegalne zamieszkiwanie budynków, chuligaństwo, homofobia, obrót bronią etc.), poszerzając uprawnienia organów ścigania w tym zakresie (Loi pour la sécurité intérieure, 2003). Ustawa wzbudzała liczne kontrowersje, w kolejnych latach dokonywano jej nowelizacji.

Druga ustawa o kierunkach i programowaniu w zakresie bezpieczeństwa wewnętrznego, czyli LOPPSI II, została przyjęta w 2011 r. Wzięto pod uwagę współczesne zagrożenia, np. cyberprzestępczość, dokonano penalizacji kradzieży tożsamości w Internecie oraz rozpowszechnia pornografii nieletnich, co zresztą zostało poddane krytyce jako rodzaj cenzury. Inne obszary, które reguluje LOPPSI II, to: identyfikacja osób na podstawie badania DNA; monitoring i kontrola policyjnych baz danych; wprowadzenie terminu „,video-ochrona” (fr. vidéoprotection), który zastąił wprowadzony przez ustawę z 1995 r. termin „,video-nadzór” (fr. vidéosurveillance), wzmocnienie środków ochrony prawnej agentów służb specjalnych oraz źródeł informacji, a także współpracowników, dalsze wzmacnianie środków w zakresie walki z przestępczością oraz środków w zakresie prewencji (Loi d'orientation et de programmation pour la sécurité intérieure, 2011: art. 18).

$* * *$

Podjęty problem funkcjonowania ustaw o bezpieczeństwie wewnętrznym, przyjmowanych w państwach takich, jak Indie, Portugalia oraz Francja jest obecnie zagadnieniem aktualnym o tyle, że w 2016 r., w momencie składania tego artykułu do druku, przez Polskę przetoczyła się dyskusja na temat ustawy antyterrorystycznej planowanej w zwiazku z przypadającymi w tym roku Światowymi Dniami Młodzieży oraz szczytem Organizacji Paktu Północnoatlantyckiego, które mają się odbywać w Polsce. Coraz częstsze ataki terrorystyczne skłaniają współczesne państwa do zaostrzania środków prawnych, mających na celu poprawę bezpieczeństwa obywateli. Biorąc to pod uwagę, można sformułować następujące wnioski, będące wynikiem badań przeprowadzonych w artykule.

Po pierwsze, rozwiązania na gruncie prawnym w zakresie ochrony bezpieczeństwa wewnętrznego, przyjmowane przez różne państwa są pokłosiem szeregu czynników, występujących w tych państwach, chociażby: prowadzonej przez nie polityki i charyzmy ich przywódców (rządy Indiry Ghandi w Indiach i kwestia Pakistanu, przełom w Portugalii lub dojście do władzy Nicolasa Sarkozy’ego we Francji), siły systemu prawnego i zaufania do niego (co widać zwłaszcza w przypadku Francji), także członkostwo (bądź jego brak) w danych organizacjach międzynarodowych, takich jak np. Unia Europejska (w przypadku Portugalii i Francji).

Po drugie, niewątpliwą zaletą ustaw o bezpieczeństwie wewnętrznym jest (bądź też powinno być) zdefiniowanie pojęcia bezpieczeństwa wewnętrznego. Ma to miejsce 
w przypadku ustaw przyjętych w Portugalii oraz we Francji. Ustawowa definicja wytycza nurt pojmowania bezpieczeństwa wewnętrznego w danym państwie.

Po trzecie, w przypadkach omawianych państw bezpieczeństwo wewnętrzne rozumie się zazwyczaj raczej wąsko tj. utożsamia się je z zakresem pojęciowym bezpieczeństwa publicznego i porządku publicznego, jak ma to miejsce w przypadkach Indii i Francji. To wąskie ujęcie może stanowić powód do krytyki przyjmowanych rozwiązań bądź budzić kontrowersje (np. kwestia prewencyjnego uwięzienia w Indiach). Poszerzone ujęcie bezpieczeństwa wewnętrznego przyjęła Portugalia, włączając w jego ustawową definicję także kwestię ochrony ludzi w czasie klęsk i katastrof żywiołowych.

Przytoczone wnioski oznaczają, że założona na wstępie hipoteza badawcza znalazła potwierdzenie. Budowanie efektywnego systemu bezpieczeństwa wewnętrznego w danym państwie powinno bazować na wypracowanej definicji bezpieczeństwa wewnętrznego, a definicja taka może znaleźć się właśnie w ustawie o bezpieczeństwie wewnętrznym.

\section{BIBLIOGRAFIA}

Abraham C. M. (1993), India - an overview, w: Preventive detention and security law: A comparative survey, (eds.) A. Harding, J. Hatchard, Dordrecht, Boston.

Constitution of the Portuguese Republic (1976), Lisboa.

Costa A. (2007), Uma reforma para seis problemas, „Diário de Notícias”, 11.03.2007, $\mathrm{http}: / /$ www.dn.pt/Inicio/interior.aspx?content_id=654111 (26.08.2011).

Lei de Organização da Investigação Criminal (2008), „Diário da República”, 27.08.2008, No. 165.

Lei de Segurança Interna (2008), „Diário da República”, 29.08.2008, No. 167.

Loi d'orientation et de programmation pour la performance de la sécurité intérieure (2011), „Journal Officiel de la Republique Française", 15.03.2011.

Loi d'orientation et de programmation pour la sécurité intérieure (2002), „Journal Officiel de la Republique Française", 30.08.2002.

Loi d'orientation et de programmation relative à la sécurité (1995), „Journal Officiel de la Republique Française", 24.01.1995.

Loi pour la sécurité intérieure (2003), „Journal Officiel de la Republique Française”, 19.03.2003.

Loi relative à la sécurité quotidienne (2001), „Journal Officiel de la Republique Française”, 16.11.2001.

Maintenance of Internal Security Act (1971), „The Gazette of India”, No. 26.

Ramachandran S. (2015), India's Controversial Armed Forces (Special Powers) Act, „The Diplomat”, 2.07.2015, http://thediplomat.com/2015/07/indias-controversial-armed-forces-special-powers-act/ (23.04.2015).

Terrorist and Disruptive Activities (Prevention) Act (1987), „The Gazette of India”, No. 28.

The Armed Forces (Special Powers) Act (1958), „The Gazette of India”, No. 28.

The Conservation of Foreign Exchange and Prevention of Smuggling Activities Act (1974), „The Gazette of India", No. 35.

The Constitution of India (2015), New Delhi. 
The Essential Services Maintenance Act (1968), „The Gazette of India”, No. 59.

The National Security Act (1980), „The Gazette of India”, No. 65.

The Prevention of Terrorism Act (2002), „The Gazette of India”, No. 15.

\title{
STRESZCZENIE
}

Artykuł dotyczy rozwiązań prawnych w zakresie zapewniania bezpieczeństwa wewnętrznego w Indiach, Francji i Portugalii. Państwa te przyjmowały, w różnym okresie i z różnych powodów, ustawy o bezpieczeństwie wewnętrznym. Zwrócono uwagę na czynniki, które wpłynęły na ostateczny kształt uregulowań prawnych w danym państwie. Założono, że punktem wyjścia do budowania efektywnego systemu bezpieczeństwa wewnętrznego jest zdefiniowanie bezpieczeństwa wewnętrznego, a definicja taka może znaleźć się w ustawie o bezpieczeństwie wewnętrznym. Pytania badawcze dotyczą tego w jaki sposób pojmuje się bezpieczeństwo wewnętrzne na gruncie ustawodawstwa w tym zakresie w Indiach, Portugalii oraz we Francji. Artykuł kończy zestawienie wyciagniętych wniosków: po pierwsze, rozwiązania na gruncie prawnym w zakresie ochrony bezpieczeństwa wewnętrznego, przyjmowane przez różne państwa są pokłosiem szeregu czynników, występujących w tych państwach. Po drugie, w ustawach o bezpieczeństwie wewnętrznym zazwyczaj zdefiniowano termin „bezpieczeństwo wewnętrzne” (w przypadkach Portugalii i Francji). Po trzecie, w omawianych państwach bezpieczeństwo wewnętrzne rozumie się zazwyczaj raczej wąsko tj. utożsamia się je z zakresem pojęciowym bezpieczeństwa publicznego i porządku publicznego (w przypadkach Indii i Francji).

Slowa kluczowe: bezpieczeństwo wewnętrzne, Francja, Indie, Portugalia, ustawa o bezpieczeństwie wewnętrznym

\section{INTERNAL SECURITY ACTS OF INDIA, PORTUGAL AND FRANCE}

\begin{abstract}
The article concerns Internal Security Acts in India, Portugal and France. These states had adopted such kind of laws due to various reasons and motives. In the paper a set of factors is identified which have influenced internal security rules in the above-mentioned states. The key assumption is that the crucial issue is the definition of internal security which is necessary if a state would like to build an internal security system. The definition might be included in an Internal Security Act. The basic question is how internal security is understood in India, Portugal and France. The article concludes with final conclusions. First, the Internal Security Acts adopted by various states are influenced by a set of factors occurring in these states. Secondly, usually the concept of internal security has been defined by an Internal Security Act (Portugal and France cases). Last but not least, the internal security is understood in a narrow way i.e. it is restricted to the issues of public order and public security (India and France cases).
\end{abstract}

Key words: France, India, internal security, Internal Security Act, Portugal 